\title{
Physical and chemical characterization and quantification of bioactive compounds in berries and berry jams
}

\section{Caracterização físico-química e quantificação dos compostos bioativos em pequenas frutas e em suas geleias}

\author{
Lorena Mendes Rodrigues ${ }^{1 *}$; Diene France de Souza ${ }^{2}$; \\ Elisângela Aparecida da Silva ${ }^{3}$; Thaís Odete de Oliveira ${ }^{4}$; Juliana Pinto de Lima ${ }^{5}$
}

\begin{abstract}
Brazil is the third largest producer of fresh fruits in the world. Among fruits, berries such as strawberry, blueberry and blackberry can be highlighted for the benefits they provide to the body, owing to their presence of bioactive compound content. The phenolic compounds, especially anthocyanins and ascorbic acid, are examples of bioactive compounds that mainly function in the body as antioxidants. However, the processing steps that lead to the generation of derivatives from these fruits, are damaging to these compounds, often leading to their loss. Thus, the aim of this study was to physically and chemically characterize fresh berries (strawberry, blueberry and blackberry) and their jams, and also to quantify and to evaluate the antioxidant activity of bioactive compounds in berries and their jams. The following parameters were analyzed: moisture, ash, $\mathrm{pH}$, titratable acidity, soluble solids, and color. The levels of total phenolic compounds, total anthocyanins, ascorbic acid content and antioxidant activity were measured. We concluded that there were significant differences in the chemical composition of berries and jams. There was also a significant loss of bioactive compounds due to processing, nevertheless these jams remain good sources of bioactive compounds, and are still considered important to promote some favorable health effects.
\end{abstract}

Key words: Berries. Processing. Secondary metabolites.

\section{Resumo}

O Brasil é o terceiro maior produtor de frutas frescas do mundo. Dentre essas, os pequenos frutos como morango, mirtilo e amora-preta se destacam, devido aos benefícios que proporcionam ao organismo, que são consequência da presença dos compostos bioativos. Os compostos fenólicos, em especial as antocianinas e o ácido ascórbico, são exemplos de bioativos, que têm como principal função no organismo a atividade antioxidante. No entanto, as etapas do processamento de derivados a partir destes frutos agem de forma negativa, ou seja, levam a perda desses compostos. Assim, o objetivo deste trabalho foi caracterizar físico-quimicamente as pequenas frutas (morango, mirtilo e amora-preta) in natura e as geleias das mesmas e quantificar e avaliar a atividade antioxidante dos compostos bioativos nas frutas e nas geleias. Para atingir esse objetivo foram realizadas as seguintes análises: umidade,

${ }^{1}$ Discente, Curso de Mestrado do Programa de Pós-Graduação em Ciência dos Alimentos, Universidade Federal de Lavras, UFLA, Lavras, MG, Brasil. E-mail: lorii_mendes@hotmail.com

${ }^{2}$ Discente, Curso de Mestrado do Programa de Pós-Graduação em Ciência dos Alimentos, UFLA, Lavras, MG, Brasil. E-mail: dienesouza_@hotmail.com

3 Bolsista, Pós-Doutorado, Embrapa Café, Inovacafé, Campus da UFLA, Lavras, MG, Brasil. E-mail: agroelis@yahoo.com.br

${ }^{4}$ Prof $^{\mathrm{a}}$ M.e, Instituto Federal de Educação, Ciência e Tecnologia do Sudeste de Minas Gerais, IF Sudeste MG, Campus Barbacena, Barbacena, MG, Brasil. E-mail: thais.odete@ifsudestemg.edu.br

${ }^{5}$ Prof $^{\mathrm{a}} \mathrm{Dr}^{\mathrm{a}}$, Instituto de Ciências Agrárias, Universidade Federal de Minas Gerais, UFMG, Montes Claros, MG, Brasil. E-mail: juliana pinto_lima@hotmail.com

* Author for correspondence 
cinza, $\mathrm{pH}$, acidez titulável, sólidos solúveis e coloração. Também foram quantificados os teores de compostos fenólicos totais, antocianinas totais, ácido ascórbico e a atividade antioxidante. Pode-se concluir que ocorreu diferenças significativas na composição centesimal dos frutos e das geleias. Houve perdas significativas dos compostos bioativos devido ao processamento, contudo as geleias produzidas ainda apresentaram boas fontes de compostos boativos, sendo ainda consideradas importantes para promover alguns efeitos favoráveis à saúde.

Palavras-chave: Frutas vermelhas. Metabólitos secundários. Processamento.

\section{Introduction}

Brazil is the third largest producer of fresh fruits in the world (OCDE-FAO, 2015). Among these fruits, we can find small berries, which are fleshy fruits (SOUZA et al., 2014), widely accepted, because of their appearance and attractive flavor. Berries are consumed both as fresh fruit and in their processed forms, such as spreads, jams, syrups, wines, teas, and dairy products (CURI et al., 2016; KADIVEC et al., 2013). In addition to their organoleptic characteristics, berry fruits, are notably rich in phytochemicals, which if present in the diet, may have health benefits (VIZZOTTO, 2012).

Bioactive compounds are mostly secondary plant metabolites, usually found in small amounts in food, but are beneficial to the maintenance of human health (CARRATUं; SANZINI, 2005; COSTA et al., 2013). Some groups of bioactive compounds include minerals and vitamins, antioxidants, polyunsaturated fatty acids, and phenolic compounds (MORAES; COLLA, 2006).

Antioxidants act in the body against free radicals and highly reactive oxygen species. Vitamin $\mathrm{C}$ (ascorbic acid) is considered the most important hydrosoluble antioxidant in the body (COUTO; CANNIATTI-BRAZACA, 2010).

Phenolic compounds can be highlighted among bioactive compounds, and are divided in flavonoid and non-flavonoid (BURNS et al., 2001; MELO; GUERRA, 2002). Anthocyanins are hydrosoluble pigments encountered in the Plantae kingdom (DEGÁSPARI; WASZCZYNSKYJ, 2004), and of the main flavonoid classes, that contribute to antioxidant activity (SU; CHIEN, 2007).
The bioactive content of food is influenced by genetic factors, environmental conditions, ripeness, and cultivar, among others. Furthermore, during food processing, numerous chemical and enzymatic reactions may affect the content, activity and availability of these compounds (KADIVEC et al., 2013; MELO et al., 2009). One of the processes, that may affect bioactive compounds is jam making, because the fruits are subjected to high heat during cooking. In this process, fruits are combined with sugar in different proportions, and then subjected to heating for gel formation and consequently, the production of the fruit jams (SEO et al., 2016). Nonetheless, to the best of our knowledge, very little information is available on the influence of processing on the content of bioactive compounds in berry jams.

In this context, the objectives of the present research were: (a) physically and chemically characterize the berries (strawberry, blueberry and blackberry) in natura; (b) to evaluate the physicalchemical characteristics of jams made with berries; (c) to investigate the influence of processing on bioactive compounds and the antioxidant capacity of berries jams.

\section{Materials and Methods}

Three berries were characterized: strawberry, blueberry, and blackberry. The fruits were donated by the Empali Indústria e Comércio de Alimentos Ltda company (Barbacena - MG). The fruits were of perfect quality, without any detectable visual damage, of adequate sensorial and microbiological characteristics, and previously sanitized. 
To obtain fruit purees, the fruits were crushed for $2 \mathrm{~min}$ in an industrial blender with a $2.0 \mathrm{~L}$ capacity at 3,500 rpm. Jams were prepared with four formulations (fruit + white refined sugar): 1) $50 \%$ strawberry fresh matter and 50\% sugar; 2) $50 \%$ blueberry fresh matter and 50\% sugar; 3) 50\% blackberry fresh matter and 50\% sugar and 4) 50\% mixed fruits (strawberry, blueberry, and blackberry fresh matter, with a $33.33 \%$ content of each fruit) and $50 \%$ sugar. To the four formulations, $1.0 \%$ high methoxyl pectin and $0.1 \%$ citric acid were added.

Briefly, for the preparation of fruit jams, sugar was added to the fruit purees, and then the process was carried out in an open pan heated on a medium gas flame. After boiling, pectin was added under manual agitation. The $\mathrm{pH}$ value was adjusted by the addition of citric acid to reach a $\mathrm{pH}$ of 3.0-3.2, ideal for gel formation. Throughout the process, the total soluble solids were determined using a portable refractometer and when these reached $65^{\circ}$ Brix, cooking was stopped. When cooking was finalized, the hot jams were poured into sterile $200 \mathrm{~mL}$ glass vials, immediately capped with plastisol-lined metal lids, and inverted for 3 min to sterilize the lids and the empty space in the vials. Finally, the jams were cooled at room temperature, stored in a refrigerator at $7{ }^{\circ} \mathrm{C}$, and kept in darkness (no light exposure) until analysis.

The following physical and chemical analyses were carried out with six repeats: $\mathrm{pH}$ and soluble solids, according to AOAC (2000); moisture and ash contents were calculated through gravimetry and titratable acidity was carried out through titration with sodium hydroxide solution $(\mathrm{NaOH})$ $0.1 \mathrm{~N}$, according to the Adolf Lutz Institute (1985).

External color was determined at two distinct spots on the fruits and in jam portions with a Konica Minolta CM-5 colorimeter. For color measurements, we obtained the $L^{*}, a^{*}$, and $b^{*}$ parameters with values ranging from 0 to 100 (black to white), -80 to +100 (green to red), and -50 to +70 (blue to yellow). Hue angle $\left({ }^{\circ}\right.$ hue $)$ was calculated with the formula:

$$
{ }^{\circ} \text { hue }=\operatorname{Tan}^{-1}\left(\mathrm{~b}^{*} \mathrm{a}^{*-1}\right)
$$

The antioxidant and total phenolic extracts were obtained according to the method described by Larrauri et al. (1997). Briefly, $2 \mathrm{~g}$ of samples, to which $20 \mathrm{~mL}$ methyl alcohol at 50\%, was added. Were homogenized and allowed to rest for $1 \mathrm{~h}$ at room temperature. After this period, the mixture was centrifuged at $14,000 \mathrm{rpm}$ for $15 \mathrm{~min}$. The supernatant was collected, and $20 \mathrm{~mL}$ acetone were added to the residue, which was again homogenized and allowed to rest for $1 \mathrm{~h}$, at room temperature. Then, the sample was centrifuged at 14,000 rpm for $15 \mathrm{~min}$. The supernatant was collected and added to the first supernatant, and the volume was brought up to $50 \mathrm{~mL}$ with distilled water.

The total phenolic content was determined based on the adapted Folin-Ciocalteau method (WATERHOUSE, 2002) using the Folin-Ciocalteau reagent. In short, $0.5 \mathrm{~mL}$ extracts from each sample were added to tubes containing $2.5 \mathrm{~mL}$ of FolinCiocalteau solution at $10 \%$. Then, $2 \mathrm{~mL}$ of $4 \%$ sodium carbonate solution was added. The tubes were agitated and allowed to rest for $2 \mathrm{~h}$ protected from light. The blue color produced by the reduction of the Folin-Ciocalteau reagent by phenolic compounds was measured via spectrophotometry, at a wavelength of $750 \mathrm{~nm}$. Phenolic content was calculated from the equation of the line obtained from the standard curve of gallic acid. Results were expressed in mg of gallic acid equivalents per $100 \mathrm{~g}$ sample (mg GAE $100 \mathrm{~g}^{-1}$ ).

The method used to determine antioxidant activity of jams is based on the extinction in the absorption of the 2,2-diphenyl-1-picryl hydrazyl radical (DPPH $60 \mu \mathrm{M}$ ), proposed by Rufino et al. (2007a), with some modifications. We calculated DPPH radical sequestration from the standard. Briefly, $0.1 \mathrm{~mL}$ of each sample extract was added to $3.9 \mathrm{~mL}$ DPPH solution. As a control, $0.1 \mathrm{~mL}$ methanol was added to DPPH instead of the extract. Readings were carried out $120 \mathrm{~min}$ later, in a spectrophotometer, at a wavelength of $515 \mathrm{~nm}$, 
and the results were expressed as a percentage of free radical sequestration ( $\% \mathrm{FRS})$, according to the following equation:

$$
\% \mathrm{FRS}=(\mathrm{Ac}-\mathrm{Am}) \times 100 \mathrm{Ac}^{-1}
$$

Where $\mathrm{Ac}=$ control absorbance Am = sample absorbance

The method used to determine the antioxidant activity of berries was described by Rufino et al. (2007b), using ABTS radical (2,2-azinobis3-ethylbenzothiazoline-6-sulfonic acid). As a reference, we used Trolox, a synthetic antioxidant vitamin $\mathrm{E}$ analogue, and the results were expressed in $\mu \mathrm{M}$ Trolox $\mathrm{g}^{-1}$.

The total monomeric anthocyanin content (TMAC) was estimated using the $\mathrm{pH}$ differential method (GIUSTI; WROSLTAD, 2001), in which the sample is dissolved in two buffer systems: potassium chloride, $\mathrm{pH} 1.0(0.025 \mathrm{M})$ and sodium acetate, $\mathrm{pH}$ $4.5(0.4 \mathrm{M})$. A $2.5 \mathrm{~mL}$ volume of the corresponding buffer was added to $1.5 \mathrm{~mL}$ of a fruit or jam sample, previously homogenized (to obtains optical density in the band width from 0.100 to 1.200 , at $510 \mathrm{~nm}$ ). The absorbance was measured at $510 \mathrm{~nm}$ and 700 $\mathrm{nm}$ at both $\mathrm{pH} 1.0$ and $\mathrm{pH} 4.5$. Then, the TMAC was calculated using the following formula:

$$
\mathrm{A}=\left(\mathrm{A}_{510 \mathrm{~nm}}-\mathrm{A}_{700 \mathrm{~nm}}\right)_{\mathrm{pH} 1.0}-\left(\mathrm{A}_{510 \mathrm{~nm}}-\mathrm{A}_{700 \mathrm{~nm}}\right)_{\mathrm{pH} 4.5}
$$

$\mathrm{TMAC}=(\mathrm{A} \times \mathrm{MW} \times \mathrm{DF} \times \mathrm{EV} \times 1000)(\varepsilon \times 1 \times M)^{-1}$

Where: $\mathrm{A}=$ absorbance; $\mathrm{MW}=$ molecular weight of cyanidin-3-glucoside; DF = dilution fator; EV: extract volume; $\varepsilon=$ molar extinction coefficient of cyanidin-3-glucoside, and $M$ mass of the berries and jams extracted.

The results were expressed as mg cyanidin-3glucoside equivalents $(100 \mathrm{~g})^{-1}$.

Ascorbic acid content was determined using the colorimetric method, using 2,4-dinitrophenylhydrazine, according to Strohecker and Henning (1967). The reading were carried out in a computerized Beckman 640B spectrophotometer, and the results were expressed in mg of ascorbic acid per $100 \mathrm{~g}$ extract.

All data are expressed as mean \pm standard deviation (SD). The experiment had a randomized design with three replicates, the obtained results underwent variance analysis and the averages were compared using the Scott-Knott test $(p \leq 0.05)$, and the SISVAR statistic software (FERREIRA, 2011).

\section{Results and Discussion}

\section{Physicochemical parameters of berries}

The results regarding the color, moisture, ash, $\mathrm{pH}$, titratable acidity, and soluble solids of berries (strawberry, blackberry and blueberry) are presented in Table 1.

With respect to the color of fruits, the color parameter $\mathrm{L}^{*}$ ranged from 20.5 to 35.2 , the color parameter $\mathrm{a}^{*}$ ranged from 5.8 to 33.2 , and the color parameter $b^{*}$ ranged from 1.0 to 18.75 . There were significant differences in the $\mathrm{L}^{*}, \mathrm{a}^{*}, \mathrm{~b}^{*}$, and ${ }^{\circ}$ hue variables, the strawberry presented higher values for these variables than the other berries. In increasing order of ${ }^{\circ}$ hue, the different samples were arranged as follows: blueberry (9.78) closer to purplish red; blackberry (18.43) between purplish red and red; and strawberry (29.13) closest to red.

With respect to the color of fruits, the color parameter $\mathrm{L}^{*}$ ranged from 20.5 to 35.2 , the color parameter $\mathrm{a}^{*}$ ranged from 5.8 to 33.2 , and the color parameter $\mathrm{b}^{*}$ ranged from 1.0 to 18.75 . There were significant differences in the $\mathrm{L}^{*}, \mathrm{a}^{*}, \mathrm{~b}^{*}$, and ${ }^{\circ}$ hue variables, the strawberry presented higher values for these variables than the other berries. In increasing order of ${ }^{\circ}$ hue, the different samples were arranged as follows: blueberry (9.78) closer to purplish red; blackberry (18.43) between purplish red and red; and strawberry (29.13) closest to red. 
Table 1. Color, moisture, ash, $\mathrm{pH}$, total acidity and soluble solids ( $\left.{ }^{\circ} \mathrm{Brix}\right)$ of blueberry, blackberry, and strawberry averages ${ }^{(1)}$.

\begin{tabular}{|c|c|c|c|c|}
\hline \multicolumn{5}{|l|}{ Variables Berries } \\
\hline & & Blueberry & Blackberry & Strawberry \\
\hline \multirow{4}{*}{ Color } & $\mathrm{L}^{*}$ & $20.50 \pm 8.26 b$ & $23.00 \pm 2.51 \mathrm{~b}$ & $35.20 \pm 3.01 \mathrm{a}$ \\
\hline & $a^{*}$ & $5.80 \pm 1.15 \mathrm{c}$ & $24.90 \pm 3.26 b$ & $33.20 \pm 2.34 \mathrm{a}$ \\
\hline & $\mathrm{b}^{*}$ & $1.00 \pm 0.36 \mathrm{c}$ & $8.30 \pm 1.45 \mathrm{~b}$ & $18.50 \pm 2.85 \mathrm{a}$ \\
\hline & ${ }^{\circ}$ hue & $9.78 \pm 1.47 \mathrm{c}$ & $18.43 \pm 1.19 \mathrm{~b}$ & $29.13 \pm 2.56 \mathrm{a}$ \\
\hline \multicolumn{2}{|c|}{ Moisture (\%) } & $82.80 \pm 0.75 \mathrm{c}$ & $89.00 \pm 0.63 \mathrm{~b}$ & $91.70 \pm 0.52 \mathrm{a}$ \\
\hline \multicolumn{2}{|c|}{ Ash (\%) } & $0.25 \pm 0.10 \mathrm{a}$ & $0.35 \pm 0.14 \mathrm{a}$ & $0.38 \pm 0.04 \mathrm{a}$ \\
\hline \multicolumn{2}{|c|}{$\mathrm{pH}$} & $3.13 \pm 0.02 \mathrm{c}$ & $3.38 \pm 0.02 b$ & $3.50 \pm 0.05 \mathrm{a}$ \\
\hline \multicolumn{2}{|c|}{ Total acidity $\left(\mathrm{mg}\right.$ citric acid $\left.100 \mathrm{~g}^{-1}\right)$} & $0.33 \pm 0.10 \mathrm{c}$ & $1.01 \pm 0.10 \mathrm{~b}$ & $1.41 \pm 0.15 \mathrm{a}$ \\
\hline \multicolumn{2}{|c|}{${ }^{\circ}$ Brix $(\%)$} & $5.33 \pm 0.75 \mathrm{c}$ & $7.83 \pm 0.52 b$ & $10.17 \pm 0.41 \mathrm{a}$ \\
\hline
\end{tabular}

${ }^{(1)}$ Averages with different letters in the same line are significantly different through Scott-Knott test $(\mathrm{p} \leq 0,05)$.

All fruits had high moisture content, ranging from $82.8 \%$ (blueberry) to $91.7 \%$ (strawberry). Françoso et al. (2008), found 93.08\% moisture value for strawberries, a value close to the one we calculated (91.7\%). Moraes et al. (2007), identified a moisture range between $81.3 \%$ and $8 \%$ for blueberries, in agreement with the $82.8 \%$, value we found in this study. Souza et al. (2014) calculated the moisture value in blackberries at $87.92 \%$, which is close to the one in our study.

There was no significant difference among the analyzed fruits regarding ash content. The analysis of blueberry revealed an ash content of $0.25 \mathrm{~g}(100 \mathrm{~g})$ ${ }^{-1}$, a value slightly higher than the one found by Moraes et al. (2007), which ranged from 0.1 to $0.22 \mathrm{~g}$ $(100 \mathrm{~g})^{-1}$. Hirsch et al. (2012) detected ash values in blackberry ranging from 0.27 to $0.51 \mathrm{~g}(100 \mathrm{~g})^{-1}$, in agreement with the value we found $(0.35 \mathrm{~g}(100 \mathrm{~g})$ $\left.{ }^{-1}\right)$. Françoso et al. (2008) described ash values in strawberries ranging from 0.36 to $0.52 \mathrm{~g}(100 \mathrm{~g})^{-1}$, and the value found in this study is within this range $\left(0.38 \mathrm{~g}(100 \mathrm{~g})^{-1}\right)$.

The samples showed significant $\mathrm{pH}$ differences, and the one with lowest value and most acidity, was blueberry, followed by blackberry and strawberry. The $\mathrm{pH}$ value of blueberry found in this study was higher than the one found by Moraes et al. (2007), which ranged from 2.56 to 2.67. Jacques and Zambiazi (2011), described blackberry pH values between 2.33 and 3.40, and our result is within this range.

Acidity is one of the criteria that affect the classification of fruit. Fruits with levels of citric acid ranging from 0.08 to $1.95 \%$ can be classified as mild in flavour, and are well accepted for consumption in natura (PAIVA et al., 1997). All samples differed from one another with respect to titratable acidity. Moura et al. (2011) found the titratable acidity values for blueberry ranging from 0.58 to 0.63 (mg citric acid $(100 \mathrm{~g})^{-1}$ ), whereas we found a lower value (0.33). Hirsch et al. (2012) found titratable acidity values for blackberry between 1.27 and 1.62 $\left(\mathrm{mg}\right.$ citric acid $\left.(100 \mathrm{~g})^{-1}\right)$, values that are lower than the one found in this study (1.41).

The soluble solids content is an important characteristic for products that are sold fresh, since consumers have a preference for sweeter fruits (MAHMOOD et al., 2012; SILVA et al., 2002). With respect to soluble solids, all the samples showed considerable differences in soluble solid content, strawberry being the fruit with the highest value (10.17\%). The soluble solid content (10.50\%) found in strawberry by Souza et al. (2014) is very similar to the one found in our study. However, the values found by the same authors for blackberry $(10.17 \%)$ and blueberry (14.67) are much higher than those present in our fruit samples. 


\section{Physicochemical parameters of jams}

The results regarding the color, moisture, ash, $\mathrm{pH}$, titratable acidity, and soluble solids of jams (strawberry, blackberry, blueberry and mixed) are presented in Table 2.

Table 2. Color, moisture, ash, $\mathrm{pH}$, total acidity and soluble solids ( ${ }^{\circ}$ Brix) of blueberry jam, blackberry jam, strawberry jam and mixed jam averages $\left({ }^{2}\right)$.

\begin{tabular}{lcrrrr}
\hline \multicolumn{6}{l}{ Variables Jams } \\
\hline
\end{tabular}

${ }^{(2)}$ Averages with different letters in the same line are significantly different through Scott-Knott test $(p \leq 0,05)$.

With regard to color, the only jam that was significant different from the others, for the value of the $\mathrm{L}^{*}$ coordinate, was strawberry jam, which was lighter than the others. Based on the increasing value for ${ }^{\circ}$ hue, the jams were ordered as follows: blueberry (8.4), blackberry (13.3), and mixed (10.2), closer to purplish red; strawberry (31.9), closer to red.

The coloration is generally the first characteristic observed in fresh foods, and very often predetermines the consumer expectation in relation to the flavor and quality. However, during food processing, for example in the production of jams, a change in the color of the original fruit commonly occurs (KOVACEVIC et al., 2015). This can be explained by many factors, such as darkening reactions (the Maillard reaction) and the degradation of pigments responsible for fruit coloring, such as anthocyanin, that is the main pigment in berries (CURI et al., 2016). Although a comparative statistical analysis of the colors of the fruits in natura and jams was not carried out, it could be verified that the a* value decreased in the jellies, indicating that the jams had a lower intensity of red coloring compared to the intensity of the fruit in natura.

Moisture values for blueberry, blackberry, and mixed jams did not differ. Mota (2006) found moisture values ranging from 42.84 to $46.44 \%$ for blackberry jam. The value found in our study, $43.4 \%$ is similar to the previously reported results.

With respect to ash content, all jams differed from one another. Zambiazi et al. (2006) found a strawberry jam ash content of $0.26 \%$, compared to the higher value of $0.57 \%$, found in this study.

Jam $\mathrm{pH}$ values were not considerable different from one another, having a mean value of 3.24. Carneiro et al. (2012) found a $\mathrm{pH}$ value of 3.79 for strawberry jam, whereas we obtained a value of 3.12, lower than the one found by the authors. However, our result closer to that found by Curi et al. (2016) for strawberry jellies obtained from different cultivars (2.98 - 3.19). Previously, Carneiro et al. (2016) studied blackberry jam, and obtained a pH value of 3.16, a slightly lower value than the one we obtained (3.22). 
The only jam that differed from the others with respect to the titratable acidity was strawberry jam, which showed a higher percentage of acidity. The values we found for all analyzed jams are in accordance with the ones identified by Torrezan (1998) for the production of jellies -0.5 to $0.8 \%$, compared with 0.53 to $0.75 \%$ in our study.

The analysis of soluble solids in jams did not show any significant differences, with an average value of $63.6 \%$, in accordance with the range recommended by the Brazilian legislation - 62 to 65\% (BRASIL, 1978).

The edaphoclimatic (climate and soil) conditions, the ripening stage of the fruits, and the handling of the fruits are some factors that may explain the differences in the physicochemical composition of our fruits and jams, compared with the results found in the scientific literature.

\section{Bioactive compounds and antioxidant activity}

In the analysis of bioactive compounds, blueberry and blueberry jam showed the highest total monomeric anthocyanin content at 1987.72 $\mathrm{mg}$ of cyanidin 3-glucoside equivalent per $100 \mathrm{~g}$ and $517.22 \mathrm{mg}$ of cyanidin 3-glucoside equivalent per $100 \mathrm{~g}$, respectively. On the contrary strawberry and strawberry jam had the lowest content at 139.92 $\mathrm{mg}$ of cyanidin 3-glucoside equivalent per $100 \mathrm{~g}$ and $33.69 \mathrm{mg}$ of cyanidin 3-glucoside equivalent per $100 \mathrm{~g}$, respectively (Table 3 ). This shows that the amount of anthocyanins in the fruits in natura and in the prepared jams are correlated, as high anthocyanin values in the fruits were also associated with high values in the jams. Pelegrine et al. (2012) measured anthocyanin levels in blueberry and blueberry jam at $175.0 \mathrm{mg}(100 \mathrm{~g})^{-1}$ and 138.14 mg (100 g) ${ }^{-1}$, respectively. Both values are lower than the ones we detected, according to Teixeira et al. (2008) anthocyanin content can be influenced by climate, temperature, and lighting, and the hinder the comparisons between two crops of same fruit.
Tha stability of anthocyanins can be influenced by numerous factors, such as, lighting, $\mathrm{pH}$, the presence of oxidizing agents, and enzymes. Therefore it is very important to study the degradation of anthocyanins in processed and stored food products (OANCEA; CALIN, 2016). When assessing the effects of processing on total anthocyanin content, we observed considerable losses in every jam, compared to the respective content in berries. Blackberry jam was the one with the largest anthocyanin loss (78.79\%). Due to the complexity of the reactions affecting anthocyanin during the cooking process, it is difficult to isolate a single factor that explains the changes in the color and in the functional properties of these pigments. However, temperature is clearly an important factor, since the degradation and polymerization induced by heating generally led to discoloration (FALCÃO et al., 2007).

When analyzing phenolic compounds, the only berry that was significant different from the others was the blueberry, with the lowest value $(296.21 \mathrm{mg}$ EAG (100) $\mathrm{g}^{-1}$, Table 3), whereas strawberry and blackberry were not significant different from each other. With regard to the phenolic compound content in jams, blackberry showed the highest content, followed by blueberry, mixed and strawberry jams, where the last two were not very different from each other, showing values of $370.04 \mathrm{mg}$ EAG $(100 \mathrm{~g})^{-1}$ and $416.55 \mathrm{mg}$ EAG $(100 \mathrm{~g})^{-1}$ (Table 3), respectively. Souza et al. (2014) measured the value for the phenolic compounds in blueberry at 305.38 mg EAG $(100 \mathrm{~g})^{-1}$, a higher result compared to the one found in this study. The same author found a phenolic compound value of $850.52 \mathrm{mg}$ EAG $(100 \mathrm{~g})$ ${ }^{-1}$ when assessing blackberry, whereas our research showed a value lower than that, at an average of $451.06 \mathrm{mg}$ EAG $(100 \mathrm{~g})^{-1}$ (Table 3$)$. The phenolic compound content for strawberries was $526.55 \mathrm{mg}$ EAG $(100 \mathrm{~g})^{-1}$ (Table 3) in our study, compared to 107.3 mg EAG $(100 \mathrm{~g})^{-1}$, as measured by Machado et al. (2013). Blackberry jam did not show any loss in the total phenolic content through processing. Conversely, strawberry and blueberry jams showed losses of 29.72 and $41.18 \%$, respectively. 


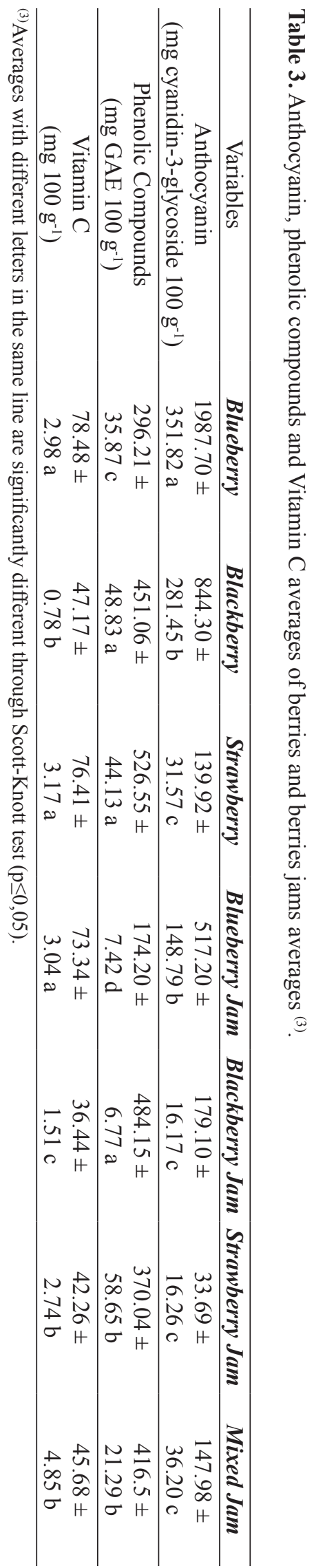

Vitamin C content was the lowest in blackberry in natura (47.17 $\left.\mathrm{mg}(100 \mathrm{~g})^{-1}\right)$ (Table 3), a result consistent with the content in the jams, as blackberry jam showed the lowest content of vitamin C (36.44 mg (100 g) ${ }^{-1}$ ) (Table 3). The vitamin $\mathrm{C}$ content for blackberry in our study was lower than the ones found by Antunes et al. (2003) -78.35 and $102.56 \mathrm{mg}(100 \mathrm{~g})^{-1}$, and similar to the one found by Souza et al. (2014) $-52.41 \pm 11.31$ $\mathrm{mg}(100 \mathrm{~g})^{-1}$. The vitamin C content in strawberry was not considerably different from the same content in blueberry, although this was not true for their respective berry jams. Blueberry jam showed a higher vitamin $\mathrm{C}$ content than strawberry jam (Table 3). This result revealed different behaviours of ascorbic acid under effect of processing. The vitamin $\mathrm{C}$ value in blueberry found by Souza et al. (2014) was $73.21 \mathrm{mg}(100 \mathrm{~g})^{-1}$, which is similar to our result, $78.48 \mathrm{mg}(100 \mathrm{~g})^{-1}$ (Table 3). Blueberry jam had the lowest vitamin $\mathrm{C}$ loss $(6.5 \%)$, followed by blackberry jam $(22.75 \%)$ and strawberry jam (44.7\%). Therefore, strawberry jam showed the highest vitamin $\mathrm{C}$ loss during processing.

Bioactive compounds found in food, such as some fruit, provide antioxidant activity in the human body. Among these, strawberry, blackberry, and blueberry are fruits with high antioxidant activity. However, food processing can negatively affect antioxidant activity, i.e., this activity may be lost during processing, especially when it includes heating. As reported by Nicoli et al. (1999), food processing may affect the content, activity and bioavailability of these compounds, since they may be degraded or leached into cooking water. Savikin et al. (2009) reported that the processing of different fruits into jam causes a reduction in the total phenolic compounds, anthocyanin, and antioxidant activity.

The fruits with the highest and lowest antioxidant activity (AA) were blackberry and blueberry, respectively. Strawberry presented a similar AA to blackberry, which was $4.36 \mu \mathrm{M}$ trolox $\mathrm{g}^{-1}$ of fruit (Figure 1). Blackberry and blueberry jams presented higher AA than the other jams (Figure 2). Souza et 
al. (2014) found AA values of $13.23 \mu \mathrm{M}$ trolox $\mathrm{g}$ ${ }^{-1}$ of fruit for blackberry and $7.87 \mu \mathrm{M}$ trolox $\mathrm{g}^{-1}$ of fruit for strawberry. Our study found lower values: $4.47 \mu \mathrm{M}$ trolox $\mathrm{g}^{-1}$ of fruit for blackberry and 4.36 $\mu \mathrm{M}$ trolox $\mathrm{g}^{-1}$ of fruit for strawberry (Figure 1). The differences between the values for the bioactive compounds presented in our study and those found in previous studies can probably be explained by the variability in factors such as climate differences, specific soil composition of each region, and the management of fruits (SOUZA et al., 2014).

Figure 1. Antioxidant activity through ABTS method, for the studied berries (strawberry, blackberry and blueberry) ${ }^{(1)}$.

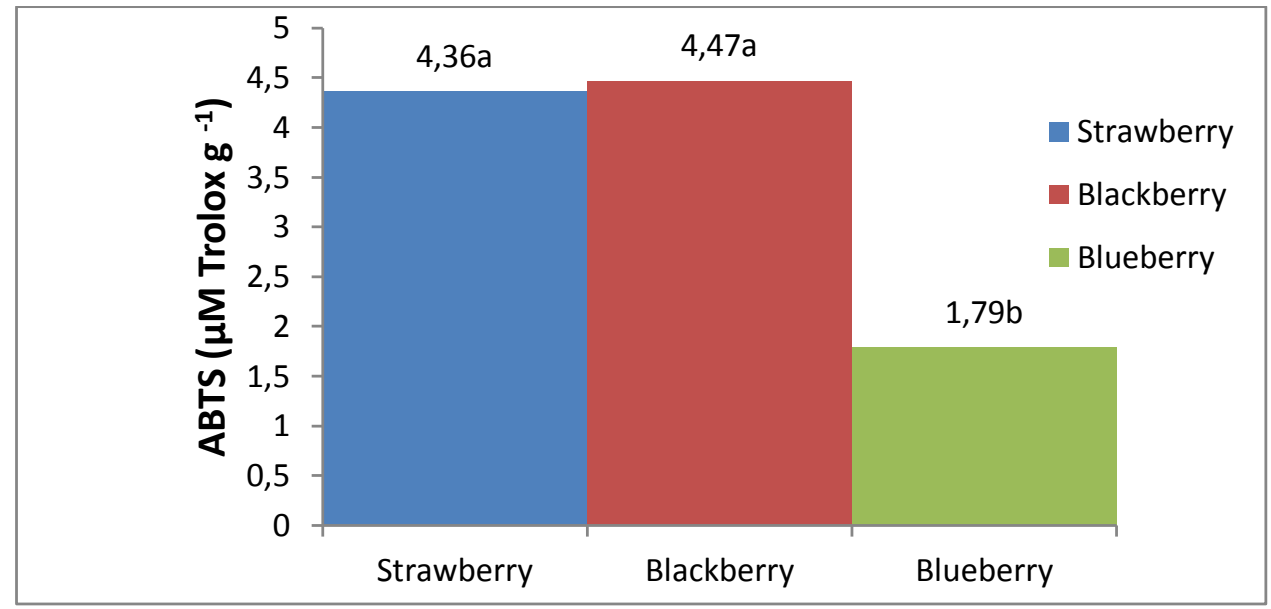

(1) Averages with different letters are significantly different through Scott-Knott test $(\mathrm{p} \leq 0,05)$.

Figure 2. Antioxidant activity through DPPH, for the jams (strawberry jam, blackberry jam, blueberry jam, and mixed jam) ${ }^{(2)}$.

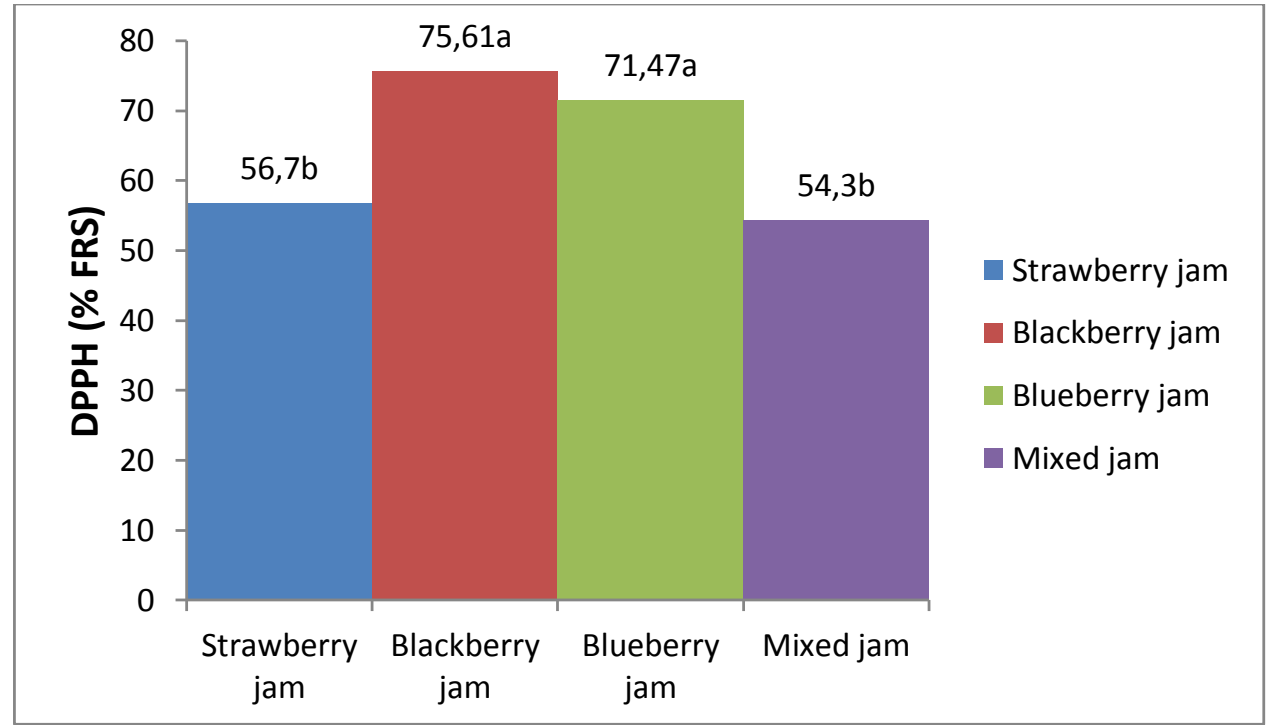

${ }^{(2)}$ Averages with different letters are significantly different through Scott-Knott test $(p \leq 0,05)$. 
With regard to the antioxidant potential of formulated jams, the four jams presented high antioxidant capacity as observed based on the DPPH radical-scavenging activity. Notably, blackberry and blueberry jams presented the highest antioxidant potential (75.61 and $71.47 \%$ FRS, respectively). We believe that the high antioxidant capacity in blackberry jam is due to its higher content in phenolic compounds, and that in blueberry jam is due to the high content of anthocyanins. Several scientific reports corroborate our hypothesis; that is, that there is a close relation between the high antioxidant activity and the total phenolic compounds and anthocyanin content in berries (CARNEIRO et al., 2016; SEO et al., 2016; SOUZA et al., 2015).

\section{Conclusions}

We identified some differences between the physical and chemical properties of berries and jams, both among them and regarding other authors.

Processing affects the content of the different bioactive compounds in the evaluated berries.

Despite the degradation of bioactive compounds that occurs during processing, which is evident when comparing fruits in natura and their jams, the jams still remain good sources of bioactive compounds and retain antioxidant potential.

\section{Acknowledgements}

To FAPEMIG, CNPq and CAPES for the financial support.

\section{References}

ANTUNES, L. E. C.; DUARTE FILHO, J.; SOUZA, C. M. Conservação pós-colheita de frutos de amoreira-preta. Pesquisa Agropecuária Brasileira, Embrapa, Brasília, v. 38, n. 3, p. 413-419, 2003.

ASSOCIATION OF OFFICIAL ANALYTICAL CHEMISTS - AOAC. Official Methods of Analysis of AOAC International. 17 $7^{\text {th }}$ ed. Gaithersburg: AOAC International, 2000. v. 2.
BRASIL. Ministério da Saúde. Agência Nacional de Vigilância Sanitária-ANVISA. Resolução de Diretoria Colegiada n. 12, de 24 de julho de 1978. Normas Técnicas Relativas a Alimentos e Bebidas. Diário Oficial [da] República Federativa do Brasil, Brasília, 1978. Seção 1, p. 1-75.

BURNS, J.; GARDNER, P. T.; MATTHEWS, D.; DUTHIE, G. G.; LEAN, M. E. J.; CROZIER, A. Extraction of phenolics and changes in antioxidant activity of red wines during vinification. Journal of Agricultural and Food Chemistry, Washington, v. 49, n. 12, p. 5797-5808, 2001.

CARNEIRO, A. P. G.; COSTA, E. A.; SOARES, D. J.; MOURA, S. M.; CONSTANT, P. B. L. Caracterização físico-química dos frutos in natura e geleias de morango e pêssego, e aspectos de rotulagem do produto ao consumidor. Revista Brasileira de Produtos Agroindustriais, Campina Grande, v. 14, n. 3, p. 295-298, 2012.

CARNEIRO, L. M.; PIRES, C. R. F.; LIMA, J. P.; PEREIRA, P. P. A.; LIMA, L. C. O. Evaluation of stability of blackberry jams conditioned in different packaging materials. Journal of Bioenergy and Food Science, Macapá, v. 3, n. 2, p. 89-102, 2016.

CARRATÙ, B.; SANZINI, E. Sostanze biologicamente attive presenti negli alimenti di origine vegetable. Annali dell'Istituto Superiore di Sanità, Roma, v. 41, n.1, p. 7-16, 2005.

COSTA, A. G. V.; GARCIA-DIAZ, D. F.; JIMENEZ, P.; SILVA, P. I. Bioactive compounds and health benefits of exotic tropical red-black berries. Journal of Functional Foods, Porto, v. 5, n. 2, p. 539-549, 2013.

COUTO, M. A. L.; CANNIATTI-BRAZACA, S. G. Quantificação de vitamina $C$ e capacidade antioxidante de variedades cítricas. Ciência e Tecnologia de Alimentos, Campinas, v. 30, n. 1, p. 15-19, 2010.

CURI, P. N.; TAVARES, B. S.; ALMEIDA, A. B.; PIO, R.; PECHE, P. M.; SOUZA, V. R. de. Influence of subtropical region strawberry cultivars on jelly characteristics. Journal of Food Science, Chicago, v. 81, n. 6, p. 515-520, 2016.

DEGÁSPARI, C. H.; WASZCZYNSKYJ, N. Propriedades antioxidantes de compostos fenólicos. Visão Acadêmica, Curitiba, v. 5, n. 1, p. 33-40, 2004.

FALCÃO, A. P.; CHAVES, E. S.; KUSKOSKI, E. M.; FETT, R.; FALCÃO, L. D.; BORDIGNON-LUIZ, M. T. Índice de polifenóis, antocianinas totais e atividade antioxidante de um sistema modelo de geleia de uvas. Ciência e Tecnologia de Alimentos, Campinas, v. 27, n. 3, p. 637-642, 2007. 
FERREIRA, D. F. Sisvar: a computer statistical analysis system. Ciência e Agrotecnologia, Lavras, v. 35, n. 6, p. 1039-1042, 2011.

FRANÇOSO, I. L. T.; COUTO, M. A. L.; CANNIATTIBRAZACA, S. G.; ARTHUR, V. Alterações físicoquímicas em morangos (Fragaria anassa Duch.) irradiados e armazenados. Ciência e Tecnologia de Alimentos, Campinas, v. 28, n. 3, p. 614-619, 2008.

GIUSTI, M. M.; WROLSTAD, R. E. Anthocyanins. Characterization and measurement with UV-Visible Spectroscopy. In: WROLSTAD, R. E. (Ed.). Current protocols in food analytical chemistry. New York: John Wiley \& Sons, 2001. Unit. p. F1.2.1-1.2.13.

HIRSCH, G. E.; FACCO, E. M. P.; RODRIGUES, D. B.; VIZZOTTO, M.; EMANUELLI, T. Caracterização físico-química de variedades de amora-preta da região sul do Brasil. Ciência Rural, Santa Maria, v. 42, n. 5, p. 942-947, 2012.

INSTITUTO ADOLFO LUTZ - IAL. Normas analíticas do Instituto Adolfo Lutz: métodos químicos e físicos para análises de alimentos. 2. ed. São Paulo: Instituto Adolfo Lutz, 1985. v. 1, 533 p.

JACQUES, A. C.; ZAMBIAZI, R. C. Fitoquímicos em amora-preta (Rubus spp). Semina: Ciências Agrárias, Londrina, v. 32, n. 1, p. 245-260, 2011.

KADIVEC, M.; BORNSEK, S. M.; POLAK, T.; DEMSAR, L.; HRIBAR, J.; POZRL, T. Phenolic content of strawberry spreads during processing and storage. Journal of Agricultural and Food Chemistry, Washington, v. 61, n. 38, p. 9220-9229, 2013.

KOVACEVIC, D. B.; PUTNIK, P.; DRAGOVICUZELAC, V.; VAHCIC, N.; BABOJELIC, M. S.; LEVAJ, B. Influences of organically and conventionally grown strawberry cultivars on anthocyanins content and color in purees and low-sugar jams. Food Chemistry, London, v. 181, p. 94-100, 2015.

LARRAURI, J. A.; RUPÉREZ, P.; SAURA-CALIXTO, F. Effect of drying temperature on the stability of polyphenols and antioxidant activity of red grape pomace peels. Journal of Agricultural and Food Chemistry, Washington, v. 45, n. 4, p. 1390-1393, 1997.

MACHADO, W. M.; PEREIRA, A. D.; MARCON, M. V. Efeito do processamento e armazenamento em compostos fenólicos presentes em frutas e hortaliças. Publicatio UEPG: Ciências Exatas e da Terra, Ciências Agrárias e Engenharias, Ponta Grossa, v. 19, n. 1, p. 1730, 2013.
MAHMOOD, T.; ANWAR, F.; ABBAS, M.; BOYCE, M. C.; SAARI, N. Compositional variation in sugars and organic acids at different maturity stages in selected small fruits from Pakistan. International Journal of Molecular Sciences, Switzerland, v. 13, n. 2, p. 1380-92, 2012.

MELO, E. A.; GUERRA, N. B. Ação antioxidante de compostos fenólicos naturalmente presentes em alimentos. Boletim Sociedade Brasileira de Ciência e Tecnologia de Alimentos (SBCTA), Campinas, v. 36, n. 1, p. 1-11, 2002.

MELO, E. A.; MACIEL, M. I. S.; LIMA, V. L. A. G.; SANTANA, A. P. M. Antioxidant capacity of vegetables submitted to thermal treatment. Nutrire-Revista da Sociedade Brasileira de Alimentação e Nutrição, São Paulo, v. 34, n. 1, p. 85-95, 2009.

MORAES, F. P.; COLLA, L. M. Alimentos funcionais e nutracêuticos: definições, legislação e benefícios à saúde. Revista Eletrônica de Farmácia, Goiânia, v. 3, n. 2, p. 109-122, 2006.

MORAES, I. V. M.; CENCI, A. S.; BENEDETTI, B. C.; MAMEDE, A. M. G. N.; SOARES, A. G.; BARBOZA, H. T. M. Características físicas e químicas de morango processado minimamente e conservado sob refrigeração e atmosfera controlada. Ciência e Tecnologia de Alimentos, Campinas, v. 28, n. 2, p. 274-281, 2008.

MORAES, J. O.; PERTUZATTI, P. B.; CORREAA, F. V.; SALAS-MELLADO, M. L. M. Estudo do mirtilo (Vaccinium ashei Reade) no processamento de produtos alimentícios. Ciência e Tecnologia de Alimentos, Campinas, v. 27, n. 1, p. 18-22, 2007.

MOTA, R. V. Caracterização física e química de geleia de amora-preta. Ciência e Tecnologia de Alimentos, Campinas, v. 26, n. 3, p. 539-543, 2006.

MOURA, G. C.; FINKENAUER, D.; CARPENEDO, S.; VIZZOTTO, M.; ANTUNES, L. E. C. Caracterização físico-química de mirtilos submetidos a diferentes coberturas de solo. Pelotas: Embrapa de Clima Temperado, 2011. 8 p. (Comunicado técnico, 266).

NICOLI, M. C.; ANESE, M.; PARPINEL, M. Influence of processing on the antioxidant properties of fruit and vegetables. Trends in Food Science \& Technology, Cambridge, v. 10, n. 3, p. 94-100, 1999.

OANCEA, S.; CALIN, F. Changes in total phenolics and anthocyanins during blackberry, raspberry and cherry jam processing and storage. Romanian Biotechnological Letters, Bucharest, v. 21, n. 1, p. 11232-11237, 2016. 
ORGANIZAÇÃO PARA A COOPERAÇÃO E DESENVOLVIMENTO ECONÔMICO E FOOD AND AGRICULTURE ORGANIZATION OF THE UNITED NATIONS - OCDE-FAO. Perspectivas Agrícolas no Brasil: desafios da agricultura brasileira 2015-2024 (tradução livre). OECD-FAO Agricultural Outlook 2015. 2015. Disponível em: <https://www.fao.org.br/ download/PA20142015CB.pdf>. Acesso em: 1 fev. 2017.

PAIVA, M. C.; MANICA, I.; FIORAVANÇO, J. C.; KIST, H. Caracterização química dos frutos de quatro cultivares e de duas seleções de goiabeira. Revista Brasileira de Fruticultura, Jaboticabal, v. 19, n. 1, p. 57-63, 1997.

PELEGRINE, D. H. G.; ALVES, G. L.; QUERIDO, A. F.; CARVALHO, J. G. Geleia de mirtilo elaborada com frutas da variedade climax: desenvolvimento e análise dos parâmetros sensoriais. Revista Brasileira de Produtos Agroindustriais, Campina Grande, v. 14, n. 3, p. 225-231, 2012.

RUFINO, M. S. M.; ALVES, R. E.; BRITO, E. S.; MORAIS, C. M.; SAMPAIO, C. G.; PÉREZ-JIMÉNEZ, J.; SAURA-CALIXTO, F. D. Metodologia cientifica: determinação da atividade antioxidante total em frutas pela captura do radical livre DPPH. Fortaleza: Embrapa, 2007a. 4 p. (Comunicado técnico, 127).

Metodologia cientifica: determinação da atividade antioxidante total em frutas pela captura do radical livre ABTS. Fortaleza: Embrapa, 2007b. 4 p. (Comunicado técnico, 128).

SAVIKIN, K.; ZDUNIC, G.; JANKOVIC, T.; TASIC, S.; MENKOVIC, N.; STEVIC, T.; DORDEVIC, B. Phenolic content and radical scavenging capacity of berries and related jams from certificated area in serbia. Plant Foods for Human Nutrition, Korean, v. 64, n. 3, p. 212-217, 2009.

SEO, J. Y.; JANG, J. H.; KIM, J. S.; KIM, E. J.; KIM, J. S. Development of low-sugar antioxidant jam by a combination of anthocyanin-rich berries. Applied Biological Chemistry, Korean, v. 59, n. 2, p. 305-312, 2016.

SILVA, P. S. L.; SA, W. R.; MARIGUELE, K. H.; BARBOSA, A. P. R.; OLIVEIRA, O. F. Distribuição do teor de sólidos solúveis totais em frutos de algumas espécies de clima temperado. Revista Caatinga, Mossoró, v. 15, n. 1-2, p. 19-23, 2002.
SOUZA, V. R.; PEREIRA, P. A. P.; SILVA, T. L. T.; LIMA, L. C. O.; PIO, R.; QUEIROZ, F. Determination of the bioactive compounds, antioxidant activity and chemical composition of Brazilian blackberry, red raspberry, strawberry, blueberry and sweet cherry fruits. Food Chemistry, London, v. 156, n. s/n, p. 362-368, 2014.

SOUZA, V. R.; PEREIRA, P. A. P.; TEIXEIRA, T. R.; SILVA, T. L. T.; PIO, R.; QUEIROZ, F. Influence of processing on the antioxidant capacity and bioactive compounds in jellies from different blackberry cultivars. International Journal of Food Science and Technology, London, v. 50, n. 7, p. 1658-1665, 2015.

STROHECKER, R. L.; HENNING, H. M. Análisis de vitaminas: métodos comprobados. Madri: Paz Montalvo, 1967. $428 \mathrm{p}$.

SU, M. S.; CHIEN, P. J.Antioxidant activity, anthocyanins, and phenolics of rabbiteye blueberry (Vaccinium ashei) fluid products as affected by fermentation. Food Chemistry, London, v. 104, n. 1, p. 182-187, 2007.

TEIXEIRA, L. N.; STRINGHETA, P. C.; OLIVEIRA, F. A. Comparação de métodos para quantificação de antocianinas. Revista Ceres, Viçosa, MG, v. 55, n. 4, p. 297-304, 2008.

TORREZAN, R. Manual para produção de geleias de frutas em escala industrial. Rio de Janeiro: Embrapa CTAA, 1998. 27 p. (Documentos, 29).

VIZZOTTO, M. Propriedades funcionais das pequenas frutas. Informe Agropecuário, Belo Horizonte, v. 33, n. 268, p. 84-88, 2012.

WATERHOUSE, A. L. Polyphenolics: determination of total phenolics. In: WROLSTAD, R. E. (Ed.). Current protocols in food analytical chemistry. New York: John Wiley \& Sons, 2002. p. 1-8.

ZAMBIAZI, R. C.; CHIM, J. F.; BRUSCATTO, M. Avaliação das características e estabilidade de geleias light de morango. Alimentos e Nutrição, Araraquara, v. 17, n. 2, p. 165-170, 2006. 